\title{
AN ANALYTICAL STUDY OF BUYING BEHAVIOUR OF BUYERS OF HEALTH INSURANCE AFTER EMERGENCE OF COVID-19 PANDEMIC
}

\author{
Dr. Neha Varshneya \\ Lecturer, Department of Business Administration, \\ S. S. Jain Subodh P.G. Mahila Mahavidyalaya, Rambag Jaipur, Rajasthan, India \\ Dr. Rajneesh Kumar Karloopia, Ph.D. \\ Central University of Rajasthan, Rajasthan, India
}

\begin{abstract}
Insurance can be termed as business which works on trust and promises. It means to keep the promises when the time comes to do so. The spread of corona virus comes as a critical time for every one and especially for the insurance companies as they have to prove that all the promises that they have made to their customers, society were true and will be kept and operated in the time of need. In the present condition when the spread of corona virus is at its peak and new to everyone, each nation is struggling with its varied form and stages. As the pandemic is spreading every country and business are facing various challenges related to logistics, labour supply, operating mechanism and supply channels, finance and liquidity, tax and trade, and strategy and brand. The insurers are looked upon by their customers with trust to address matters related to claims, withdrawals, and fund values.

The insurance industry has since beginning is linked to economic growth and prosperity. The spread of corona virus has brought major effects on insurance companies globally. The insurance industry is working hard with new and innovative rules and regulations related to work along with digital initiatives. To add on low rate of profits and growth have compelled the insurance companies to minimise the costs and improve the performance.

The present research paper is tries to study of buying behaviour of buyers of health insurance after emergence Covid-19 pandemic with special reference to Jaipur District.

Key Words: Health, Insurance, Covid-19, Pandemic, Insurer, Preferences

Cite this Article: Neha Varshneya and Rajneesh Kumar Karloopia, An Analytical Study of Buying Behaviour of Buyers of Health Insurance after Emergence of Covid-19 Pandemic, International Journal of Management, 11(12), 2020, pp 3465-3470.

https://iaeme.com/Home/issue/IJM?Volume=11\&Issue=12
\end{abstract}




\section{INTRODUCTION}

The insurance industry has since beginning is linked to economic growth and prosperity. The spread of corona virus has brought major effects on insurance companies globally. The insurance industry is working hard with new and innovative rules and regulations related to work along with digital initiatives. To add on low rate of profits and growth have compelled the insurance companies to minimise the costs and improve the performance.

Corona viruses is from a family of viruses that leads to diseases in animals and human beings. In case of human beings it has major impacts including respiratory diseases ranging from normal cold to very fatal illnesses like Middle East Respiratory Syndrome (MERS) or Severe Acute Respiratory Syndrome (SARS). The most recently identified of the corona virus's family is referred as Covid-19. Covid-19 is an infection which was not known any time until it hit Wuhan, China in the month of December, in 2019. It has spread globally now. The common symptoms of Covid-19 are fever, dry cough and tiredness. Other symptoms of the infection in some cases includes headache, sore throat, diarrhoea, and loss of taste or smell, rash on skin discoloration of fingers or toes. In the initial stage, these symptoms are usually mild but shows the effect in later on stages. It's possible that few may be infected with mild symptoms only. It is was revealed that usually $80 \%$ of the people might get well without any need of hospital treatment. But 1 out of every 5 person, it this may get very fatal with difficulty in breathing. Elderly people and the ones with some sort of previous medical history such as blood pressure related problems, heart and lungs problem, diabetes or cancer have more risk of developing this very fatal serious diseases. In this case immediate medical help is needed so it's very important to be safe and healthy. Though due to Covid-19 the insurers are in a mess but at the same time this tough phase is showing promising avenues for growth. Here are some areas of the immediate impact of Covid-19 on the insurance industry across the world:

- Travel, health, and hospitality: Covid-19 has impacted travel and hospitality industry for which new measures are being sorted out for recovery in these industries while few companies are making additions to their boxes while others are lowering the ceiling of age at purchase.

- Contingency covers: Covid-19 has led to cancellation or delay of events globally. The losses due to this have been huge.

- Cyber security: Covid-19 has led to the growth of digital economy which has made the cyber insurance sector strong.

- Commercial credit: Covid-19 has disrupted the supply chains, claims arising from nonpayments and defaults will also increase.

- Customer preferences and behaviours have shifted. - No-touch sales and underwriting processes are need of the due to corona. Increased unemployment rates compels the customers to change their pattern of spending and reshuffle the priorities- therefore, in the personal line, digital has become the enabler rather than a differentiator.

- Vehicle Miles Travelled (VMT) - Lack of mobility has resulted in less of vehicle miles travelled (VMT) which Reduces sales of vehicle. This shrinks the volumes.

- Small businesses- Small businesses have suffered a lot on account of the pandemic. In Australia, small businesses account for 35\% of the GDP and employs almost $44 \%$ of the human resources.

- In case of commercial insurance, specialty lines are suffering- While marine and aviation faced losses due to low travelling, others like construction and energy faced losses due to low volume because of low economic activity, workforce restrictions, and mobility restrictions. 
Top insurance players in 2019 had delivered given annual Total Shareholder Return (TSR) of $20 \%$ from 2014. The second quarter of 2020s showed the insurance sector underperformed in the market by $12 \%$. Thus insurance industry's relation with economic growth and its fall-out is clear. The insurance industry is working hard with new and innovative rules and regulations related to work along with digital initiatives. Reducing the gap between the decreasing sales, and revamping the outlook of risk managers, should be the approach. We can also say that this is the hot ticket for insurance company in this pandemic

A plan which covers the expenditure related to health care is health insurance. These plans comes under commercial health insurance that is given by government, private and stand-alone health insurance companies.

Health insurance is a segment of general insurance that provides $29 \%$ of premium amongst all other sectors of general insurance. But there are many problems persisting in this sector. This is the driving force behind this study. This study will help the insurance companies to know about their performance and the losses that this sector has witnessed.

Health insurance in India usually makes payments only for those patients which hospitalized. Outpatient services are not paid under health insurance policies in India. The first health insurance policy in India was Mediclaim Policy. In 2000, the Government of India provided liberty to insurance by allowing private players entry into the insurance sector. The advent of private insurers in India saw the introduction of many innovative products like family floater plans, critical illness plans, hospital cash and top-up policies.

Insurance can be termed as business which works on trust and promises. It means to keep the promises when the time comes to do so. The spread of corona virus comes as a critical time for every one and especially for the insurance companies as they have to prove that all the promises that they have made to their customers, society were true and will be kept and operated in the time of need. In the present condition when the spread of corona virus is at its peak and new to everyone, each nation is struggling with its varied form and stages. Will examination of the response of nations that are at an advanced stage in the Covid-19 war, from varied standpoints, help insurers in countries to know that they are still in the early stage of preparing a strategic response? This white paper discusses the impact of COVID-19 on insurance business from the three dimensions i.e. resilience, value, and growth, and suggests measures to address the impact.

As the pandemic is spreading every country and business are facing various challenges related to logistics, labour supply, operating mechanism and supply channels, finance and liquidity, tax and trade, and strategy and brand. The insurers are looked upon by their customers with trust to address matters related to claims, withdrawals, and fund values.

The insurance industry has since beginning is linked to economic growth and prosperity. The spread of corona virus has brought major effects on insurance companies globally. The insurance industry is working hard with new and innovative rules and regulations related to work along with digital initiatives. To add on low rate of profits and growth have compelled the insurance companies to minimise the costs and improve the performance.

\section{REVIEW OF LITERATURE}

(Singh, 2020), The current research highlights that there is still a major segment of population which is not covered health insurance products. In the recent time the sector has grown a lot which has attracted many Private Health Insurance Companies in the market along with foreign collaborators. There have been a lot of innovation in the health sector as well.

(Dutta, 2020) The study concluded that the average growth of net premium for health insurance is 135 per annum. The sector has not been able to earn underwriting profits. The 
CAGR is $27 \%$ which can be considered good rate of growth. They have been increased claims and commissions and management expenditure in the sector and it has been highest in all the past years. A high rate of growth of insurance premium also lead to more underwriting losses. Though the revenue collection has improved but the underwriting profit has not increased.

(Nair, 2019) the authors work was an attempt to do comparative study of the satisfaction in health insurance claimants of public and private sector general insurance companies. From this study it became clear that majority of the respondents were satisfied with claims reimbursement through third party administrator. The satisfaction level related to settlement of claims in public sector were at higher level as compared to private sector.

(K. Swathi, 2017), Health insurance in India- An overview. The author tries to enquire about the concept and merits of Health Insurance. It also presented an overview of Health Insurance sector in Indian country. It shows various schemes like Government sponsored, group insurance, family insurance, individual policy etc. It also highlighted sector wise health insurance policies along with providing the number of persons which were covered by the public and private insurance companies. The study suggested that government should introduce new Health Scheme which will work for the welfare of the people of the country. The Insurance Regularity and Development Authority (IRDA) should promote more in the Health Insurance Sector. Also conducting of awareness camp can be a great help in informing people about the merits of having health insurance policy.

\section{RESEARCH GAP}

After studying on the literature related to the topic it has been revealed that the segment of health insurance has been a preferable topic for researchers for conducting their studies. But with spread of corona virus its significance can be felt more. But it was found that such studies with reference to Jaipur City has been lacking thus the researchers tries to make a proper study on this area with special reference to Jaipur City which is an attempt to highlight the effects of Covid-19 on the preference of health insurance area

Covid-19: Impact on the Indian insurance industry. June 2020. PWC. The study concluded that The Covid-19 has provided the insurance companies with opportunities to review and revise their policies. Further, the automobile sector was facing fall outs before the COVID-19 outbreak and so was the motor insurance segment that accounted $35 \%$ in the overall insurance premium collection, Post pandemic there have been significant changes in the automobile insurance sector, which is one of the largest revenue sources for the general insurance industry.

\section{OBJECTIVE OF THE STUDY}

To study of buying behaviour of buyers of health insurance after emergence Covid-19 pandemic with special reference to Jaipur District.

\section{Hypothesis:}

$\mathrm{H}_{\mathrm{a}}$ : - There is significant difference in buying behavior of health insurance buyers between rural and urban area of Jaipur District.

\section{DATA ANALYSIS AND HYPOTHESIS TESTING}

To test the above mentioned hypothesis researcher has collected the data from 300 health insurance policy holders of Jaipur 150 from rural and 150 from urban area. To collect the data researcher has developed a Google questionnaire through Google forms based on Likert's Scale. Data reveals that family health policies are more preferable instead of individual health 
policies. This gives a picture that married persons have the sense of responsibility to buy the health insurance. Out of 300 policy holders 220 have the family health insurance policies.

The education status and preference towards agents also impacts the buying preference of health insurance. About $80 \%$ policy holders were stilled based on agents to buy the insurance even their education level is high.

To test the above hypothesis the researcher has applied t-test to determine whether there is a statistically significant difference between the means in two unrelated groups. The analysis and the result interpretation is given below:

Table 1

\begin{tabular}{|c|c|c|c|c|c|c|c|c|c|c|}
\hline \multicolumn{11}{|c|}{ Independent Samples Test } \\
\hline & & \multicolumn{2}{|c|}{$\begin{array}{c}\text { Levene's } \\
\text { Test for } \\
\text { Equality of } \\
\text { Variances }\end{array}$} & \multicolumn{7}{|c|}{ t-test for Equality of Means } \\
\hline & & \multirow[t]{2}{*}{$\mathbf{F}$} & \multirow[t]{2}{*}{ Sig. } & \multirow[t]{2}{*}{$\mathbf{t}$} & \multirow[t]{2}{*}{ Df } & \multirow[t]{2}{*}{$\begin{array}{l}\text { Sig. (2- } \\
\text { tailed) }\end{array}$} & \multirow[t]{2}{*}{$\begin{array}{c}\text { Mean } \\
\text { Differen } \\
\text { ce }\end{array}$} & \multirow[t]{2}{*}{$\begin{array}{l}\text { Std. Error } \\
\text { Difference }\end{array}$} & \multicolumn{2}{|c|}{$\begin{array}{l}\text { 95\% Confidence } \\
\text { Interval of the } \\
\text { Difference }\end{array}$} \\
\hline & & & & & & & & & Lower & Upper \\
\hline \multirow{2}{*}{$\begin{array}{l}\text { Health } \\
\text { Insurance }\end{array}$} & Rural & 1.751 & .175 & -2.117 & 298 & .035 & -4.0042 & 1.751 & $\begin{array}{c}- \\
7.7212 \\
\end{array}$ & -.2872 \\
\hline & Urban & & & -2.158 & $\begin{array}{c}260.6 \\
17\end{array}$ & .032 & -4.0042 & 1.748 & $\begin{array}{c}- \\
7.6583 \\
\end{array}$ & -.3501 \\
\hline
\end{tabular}

The researcher conducted the independent-samples t-test in order to compare the buying behavior and effect of covid-19 pandemic on it. Insurance is a corporate of belief, of making aptitudes, and keeping them when the time arises. The Covid-19 pandemic is a time for insurers to prove their value to customers, communities, and ultimately the economies where they operate. Given the way COVID-19 has spread around the world, nations are at different stages in battling the pandemic. The health insurance provided by state government to the people is also a supporting element that shows the impact of pandemic on health insurance in Jaipur Distict, Rajasthan as well as all over the world. The result shows that there lies significant difference in some cases. As the urban buyers have more awareness about the various factors of health insurance so they check each policy offer clearly while rural buyers believes on personal agents and relatives views. The government public insurance scheme and medical care benefits have also positive impact on buying of health insurance in the Jaipur District.

\section{REFERENCES}

[1] Dutta, M. M. (2020). Health Insurance Sector in India: An Analysis of its Performance. Vilakshan - XIMB Journal of Management.

[2] Singh, R. R. (2020, April). A Study of Health Insurance in India. International Journal of Management, IT \& Engineering, 121-134.

[3] K Swathi and R Anuradha (2017), Health insurance in India- An overview.

[4] Binny, Dr. Meenu Gupta (2017), Health insurance in India- Opportunities and challenges.

[5] BC Lakshmanna, P Jayarami Reddy, P Sravan Kumar (2019), Operational efficiency of selected general insurance companies in India. 
An Analytical Study of Buying Behaviour of Buyers of Health Insurance after Emergence of Covid-19 Pandemic

[6] Suman Devi and Dr. Vazir Singh Nehra (2015), The problems with health insurance sector in India.

[7] Satakshi Chatterjee, Dr. Arunangshu Giri, Dr. S.N. Bandyopadhyay (2018), Health insurance sector in India: A study.

[8] https://www.reliancegeneral.co.in/Insurance/Knowledge-Center/Insurance-Reads/Types-OfHealth-Insurance-Covers.Aspx

[9] https://www.acko.com/articles/health-insurance/5-types-of-health-insurance-plan-in-india/

[10] https://www.iifl.com/blogs/types-of-health-insurance-plans

[11] https://www.hdfchealth.com/knowledge-center/health-insurance-basics/types-of-healthinsurance.aspx

[12] https://www.paisabazaar.com/health-insurance/

[13] https://www.iciciprulife.com/health-insurance/types-of-health-insurance.html

[14] https://www.policybazaar.com/health-insurance/general-info/articles/how-to-calculateincurred-claim-ratio-in-health-insurance/

[15] IRDA annual reports.

[16] https://www.pwc.in/assets/pdfs/services/crisis-management/covid-19/covid-19-impact-on-theindian-insurance-industry.pdf 